\title{
Prediction of cottonseed longevity
}

\author{
Roberto Usberti(1), Eric Hywel Roberts ${ }^{(2)}$ and Richard Harold Ellis( ${ }^{(2)}$
}

(1)Coordenadoria de Defesa Agropecuária, Caixa Postal 960, CEP 13073-001 Campinas, SP, Brazil. E-mail: usberti@cati.sp.gov.br (2)The University of Reading, Department of Agriculture, Earley Gate, P.O. Box 236, Reading, RG6 6AT, United Kingdom. E-mails: roberts@blue-earth.co.uk, r.h.ellis@reading.ac.uk

\begin{abstract}
The objective of this work was to determine the viability equation constants for cottonseed and to detect the occurrence and depletion of hardseededness. Three seedlots of Brazilian cultivars IAC-19 and IAC-20 were tested, using 12 moisture content levels, ranging from 2.2 to $21.7 \%$ and three storage temperatures, 40, 50 and $65^{\circ} \mathrm{C}$. Seed moisture content level was reached from the initial value (around $8.8 \%$ ) either by rehydration, in a closed container, or by drying in desiccators containing silica gel, both at $20^{\circ} \mathrm{C}$. Twelve seed subsamples for each moisture content/temperature treatment were sealed in laminated aluminium-foil packets and stored in incubators at those temperatures, until complete survival curves were obtained. Seed equilibrium relative humidity was recorded. Hardseededness was detected at moisture content levels below 6\% and its releasing was achieved either naturally, during storage period, or artificially through seed coat removal. The viability equation quantified the response of seed longevity to storage environment well with $K_{E}=9.240, C_{W}=5.190, C_{H}=0.03965$ and $\mathrm{C}_{\mathrm{Q}}=0.000426$. The lower limit estimated for application of this equation at $65^{\circ} \mathrm{C}$ was $3.6 \%$ moisture content.
\end{abstract}

Index terms: Gossypium hirsutum, seed storage, hardseededness, viability equation.

\section{Previsão da longevidade de sementes de algodoeiro}

Resumo - O objetivo deste trabalho foi determinar as constantes da equação de viabilidade de sementes de algodoeiro e detectar a ocorrência de sementes duras. Três lotes de sementes das cultivares IAC-19 e IAC-20 foram testados, usando 12 níveis de umidade, entre 2,2 e 21,7\% e três temperaturas de armazenamento, 40, 50 e $65^{\circ} \mathrm{C}$. O grau desejado de umidade das sementes foi alcançado, a $20^{\circ} \mathrm{C}$, a partir do valor inicial (em torno de 8,8\%), por reidratação, em um recipiente fechado, ou por desidratação em dessecadores com sílica gel. Doze subamostras de sementes para cada tratamento de umidade/temperatura foram acondicionadas, em embalagens de alumínio multifoliadas, e armazenadas naquelas temperaturas, até a obtenção de curvas completas de deterioração. A umidade relativa de equilíbrio das sementes foi registrada. A presença de sementes duras foi detectada em umidades abaixo de $6 \%$ e a sua liberação foi alcançada durante o armazenamento ou por meio da remoção do tegumento da semente. A equação de viabilidade calculada foi eficaz em quantificar a resposta da longevidade das sementes em relação às condições de armazenamento por meio de $K_{E}=9,240, C_{W}=5,190, C_{H}=0,03965$ e $\mathrm{C}_{\mathrm{Q}}=0,000426$. O limite inferior estimado para aplicação dessa equação a $65^{\circ} \mathrm{C}$ foi $3,6 \%$ de umidade.

Termos para indexação: Gossypium hirsutum, armazenamento, sementes duras, equação de viabilidade.

\section{Introduction}

Cottonseed production in São Paulo State, Brazil, has being a monopoly of the Secretaria de Agricultura since 1937, aiming to ensure both good fibre pattern and plant healthiness, through special trading agreements with previously selected growers. After harvesting, seedlot quality is checked and, if approved, it is sent to processing operations which consist on shortly ginning, cleaning, mechanical delinting and packing in multifold paper bags. Cottonseed trading depends on the germination percentage value. In the last years, the annual seed demand averages in São Paulo reached 13,500 tons (crop area around 300,000 ha), with a crude value of US\$ 4,500,000.

Low germination seedlots are usually sent to industrial utilisation after the trading period. However, adverse climate conditions during the harvesting period (March-May) result in poor quality cottonseeds. Therefore, it would be wise to keep a safe regulating seed stock (close to 6,000 tons) to guarantee the following season's demand.

Hardseededness, seed coat impermeability to water, is induced in the majority of seeds of the cultivated 
Gossypium spp. when dried to 5 or $6 \%$ moisture content. In addition, all wild forms of the cultivated spp. and most wild Gossypium spp. have impermeable seed coats at low moisture contents (Ellis et al., 1985).

Longevity prediction of cotton seedlots might save money and time, allowing early sale of low-storability lots and keeping high-storability ones, either for the sale at the end of the trading period or for next season's sowing. This could be achieved using the viability equation, proposed by Ellis \& Roberts (1980), which relates seedlot viability of any initial quality to moisture and temperature, after any given storage period (Ellis et al., 1989). The equation is:

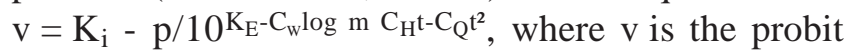
percentage viability after $\mathrm{p}$ days of storage at $\mathrm{m} \%$ moisture content (mc, f. wt. basis) and $\left({ }^{\circ} \mathrm{C}\right) ; \mathrm{K}_{\mathrm{i}}$ is a constant which stands for the initial quality of each seedlot before storage; $\mathrm{K}_{\mathrm{E}}$ is a species constant; $\mathrm{C}_{\mathrm{W}}$ indicates the logarithmic response of seed longevity to moisture content; $\mathrm{C}_{\mathrm{H}}$ and $\mathrm{C}_{\mathrm{Q}}$ are the constants of a linear and a quadratic temperature term, respectively, and describe the effect of the storage temperature on seed longevity, whereby the $\mathrm{Q}_{10}$ increases as temperature increases (Ellis et al., 1986; Kraak \& Voss, 1987).

This equation has already been applied to forest species (Dickie et al., 1990; Medeiros et al., 1998; Bonner, 1999; Chaves \& Usberti, 2004). However, viability constants are specific for each species and therefore must be determined for each species of economic, ecological and scientific interest.

The maintenance of an ex-situ germplasm bank could be relevant for conservation of such species. However, specific methodology for seed storage of that species is not available. Establishment of this methodology has been the main purpose of researchers, technologists and producers (Usberti \& Gomes, 1998).

Tropical and temperate zone species follow three seed behaviour patterns on storage: orthodox, intermediate and recalcitrant. Orthodox seeds can be conserved for a long term with low moisture content at subzero storage temperature. Intermediate species can only be conserved for a medium period as they suffer drying and cold damage at moisture content around $10 \%$, therefore showing neither an orthodox nor a recalcitrant behaviour. Recalcitrant seeds lose viability if their mc falls below a relatively high value and deteriorate rapidly, at temperatures below $15^{\circ} \mathrm{C}$, mainly.

The objective of this work was to determine the viability equation constants for cotton and to detect the occurrence and depletion of hardseededness, as to provide the safe maintenance of regulating seed stocks.

\section{Material and Methods}

Mechanical delinting (fuzzy) seeds of cotton (Gossypium hirsutum L.) from cultivars IAC-20 (seedlots 1 and 2) and IAC-19 (seedlot 3) were used. The experiment was designed and carried out in the facilities of the Seed Science Laboratory, Department of Agriculture, at University of Reading, UK.

Seeds were stored at $-20^{\circ} \mathrm{C}$ until the investigations begun. Seed moisture contents (mc) were adjusted from their initial values (around 8.8\%) before experimental storage either by rehydration above water in a closed container at $20^{\circ} \mathrm{C}$ or by drying in two phases; first in a drying cabinet at $15 \% \mathrm{RH}$ and $15-20^{\circ} \mathrm{C}$ until the mc reached $5.5 \%$ level, followed by a further drying at $20^{\circ} \mathrm{C}$ in desiccators containing silica gel, until achieving the lowest values (around 2\% level). All these procedures aimed to avoid possible fast drying damage to the seeds.

After a three-day period for stabilization at $3-5^{\circ} \mathrm{C}$, in sealed containers, seed mc was detected by the high constant temperature oven method, prescribed by the International Seed Testing Association (International Seed Testing Association, 2004), by which two 4-5 g ground seed samples were dried in a mechanically ventilated oven at $130-133^{\circ} \mathrm{C}$ for two hours.

Subsamples containing a minimum of 300 seeds, for each seedlot/mc combination, were sealed in laminated aluminium-foil packets and subsequently divided in blocks of 12 subsamples and stored in incubators maintained at 40,50 and $65^{\circ} \mathrm{C}$. Temperatures were recorded at four-hour intervals; no survival curves were analysed when the maximum allowed temperature range $\left( \pm 0.5^{\circ} \mathrm{C}\right)$ exceeded.

The highest temperature $\left(65^{\circ} \mathrm{C}\right)$ was chosen to insure that complete seed survival curves could be obtained at all moisture contents within a period of 200 days. The range of seed moisture contents stored at 40 and $50^{\circ} \mathrm{C}$ was $4.7-21.7 \%$, while at $65^{\circ} \mathrm{C}$, it was $2.2-15.8 \%$.

All seed samples showing moisture content lower than $6 \%$ were humidified above water at $20^{\circ} \mathrm{C}$ for two days, before testing, to avoid the possibility of imbibition injury during rehydration (Ellis et al., 1988). Preliminary tests did not show imbibition injury above that value.

Germination tests were performed at $25^{\circ} \mathrm{C}$, using eight replicates of 25 seeds for each mc/storage temperature, placed in rolled paper towels (Bowater T22), moistened 
with deionized water. Seed coat was removed from the seeds that had not imbibed after seven days, followed by a further period of three days for germination. When necessary, and mainly during the occurrence of hardseededness, tests were extended to a maximum of 12 days to allow adequate time for germination of all viable seeds. Seedlings were evaluated according to the criterion of normal germination (International Seed Testing Association, 2004).

Additional subsamples from all mc levels before storage were taken to detect the relation between seed $\mathrm{mc}$ and equilibrium relative humidity, at $20 \pm 0.5^{\circ} \mathrm{C}$, through a Novasina Humidat IC1, previously calibrated at 12, 55 and $94 \% \mathrm{RH}$, using appropriate standard salts (Ellis et al., 1989).

Seed survival curves were fitted to germination percentage results by probit transformation. The effect of moisture content and temperature on seed longevity was achieved using the multiple regression analysis within the generalized linear model (Baker \& Nelder, 1978; Hay et al., 2003).

\section{Results and Discussion}

Values of the intercept of the regression lines $\left(\mathrm{K}_{\mathrm{i}}\right.$, initial seedlot quality) were rather variable among seedlots. There were significant effects $(p<0.01)$ of an interaction between mc/temperature and storage period on seed longevity; however, mc/temperature combinations did not significantly affect the value of $\mathrm{K}_{\mathrm{i}}$ $(\mathrm{F}=1.80,0.93$ and 1.08, nonsignificant at $\mathrm{p}<0.01)$; constraining all curves to the same point of origin on the Y-axes yielded $\mathrm{K}_{\mathrm{i}}$ values of 2.016, 1.940 and 1.779 for seedlots 1,2 and 3, respectively.

Table 1 displays seed mc and the logarithm of the frequency distribution of seed deaths in time (sigma), at 40,50 and $65^{\circ} \mathrm{C}$ for each seedlot, after constraining all curves to the same point of origin $\left(\mathrm{K}_{\mathrm{i}}\right)$. These results, which were similar for the seedlots define, in a practical view, the logarithm of the storage period (days) required to drop seed viability of one probit, for each treatment/ seedlot.

Longevity curves obtained at 40,50 and $65^{\circ} \mathrm{C}$ for the three seedlots showed the effects of $\mathrm{mc}$ and temperature on seed storability (Figure 1). The slopes of the fitted regression lines at the same storage temperature are similar for the lots, corroborating the high precision of the results.
The residual deviances for the seedlot survival curves at different storage temperatures were analysed to provide the best fit for the viability equation. There were no statistical differences for both seedlot and interaction seedlot/log mc ( $\mathrm{F}=1.39,2.02 ; 2.81,1.36 ; 0.14,0.26$ at 40,50 and $65^{\circ} \mathrm{C}$, respectively, nonsignificant at $\mathrm{p}<0.01$ ) (Table 2). At 40 and $50^{\circ} \mathrm{C}$, residual deviances significantly decreased after removal of the results for 21.7 and $3.74 \%$ of seedlot 1 , respectively; however, at $65^{\circ} \mathrm{C}$, a better equation adjustment was achieved by removing the two lowest mc data for each seedlot (from 2.2 to $3.14 \%$ ). Therefore, the lowest mc limits for application of the viability equation at $65^{\circ} \mathrm{C}$ for each seedlot were $3.61,3.54$ and $3.67 \%$, respectively.

The constant $\mathrm{K}$ (i.e., $\mathrm{K}_{\mathrm{E}}-\mathrm{C}_{\mathrm{H}} \mathrm{t}-\mathrm{C}_{\mathrm{Q}} \mathrm{t}^{2}$ ) provides a means of simplifying the viability equation when only one temperature is considered (Ellis et al., 1986). The

Table 1. Seed moisture content and the logarithm of sigma for cotton seedlots 1, 2 (cv. IAC-20) and 3 (cv. IAC-19), stored at 40,50 and $65^{\circ} \mathrm{C}$, after constraining all survival curves to the same origin point (Ki).

\begin{tabular}{|c|c|c|c|c|c|c|c|c|c|}
\hline \multirow{3}{*}{$\begin{array}{r}\text { Moisture } \\
\text { content }(\%)\end{array}$} & \multicolumn{9}{|c|}{ Sigma (log) } \\
\hline & \multicolumn{3}{|c|}{ Seedlot 1} & \multicolumn{3}{|c|}{ Seedlot 2} & \multicolumn{3}{|c|}{ Seedlot 3} \\
\hline & $40^{\circ} \mathrm{C}$ & $50^{\circ} \mathrm{C}$ & $65^{\circ} \mathrm{C}$ & $40^{\circ} \mathrm{C}$ & $50^{\circ} \mathrm{C}$ & $65^{\circ} \mathrm{C}$ & $40^{\circ} \mathrm{C}$ & $50^{\circ} \mathrm{C}$ & $65^{\circ} \mathrm{C}$ \\
\hline 2.2 & & & 1.87 & & & & & & 1.83 \\
\hline 2.5 & & & & & & 1.96 & & & \\
\hline 3.0 & & & & & & & & & 1.95 \\
\hline 3.1 & & & 1.77 & & & 1.82 & & & \\
\hline 3.7 & & 2.73 & 1.70 & & & & & & \\
\hline 3.9 & & & & & & 1.58 & & & \\
\hline 4.1 & & & & & & & & & 1.74 \\
\hline 4.7 & & & & & & & & 2.68 & 1.39 \\
\hline 5.1 & & & & & 2.54 & 1.17 & & & \\
\hline 5.3 & & 2.28 & 1.19 & & & & & & \\
\hline 5.8 & & & & & 2.21 & 0.95 & & & \\
\hline 5.9 & & & & & & & & & 0.81 \\
\hline 6.1 & & 2.08 & 0.68 & & & & & & \\
\hline 6.3 & & & & & & & & 2.21 & \\
\hline 6.7 & & & & & 1.92 & 0.55 & & & \\
\hline 7.0 & & & & & & & 2.70 & 1.84 & 0.27 \\
\hline 7.1 & & 1.76 & 0.41 & & & & & & \\
\hline 8.8 & & & & 2.15 & 1.15 & -0.10 & & & \\
\hline 8.9 & & & & & & & 2.22 & 1.43 & -0.09 \\
\hline 9.0 & 2.17 & 1.28 & -0.20 & & & & & & \\
\hline 10.8 & 1.64 & 0.81 & -0.43 & 1.61 & 0.80 & -0.28 & & & \\
\hline 10.9 & & & & & & & 1.67 & 0.82 & -0.33 \\
\hline 12.1 & & & & 1.23 & 0.61 & -0.60 & & & \\
\hline 12.8 & 1.21 & 0.55 & -0.88 & & & & & & \\
\hline 12.9 & & & & & & & 1.34 & 0.65 & -0.65 \\
\hline 14.6 & 0.87 & 0.20 & -1.03 & & & & 0.95 & 0.22 & -1.29 \\
\hline 15.8 & & & & 0.76 & -0.03 & -1.40 & & & \\
\hline 18.1 & & & & & & & 0.27 & -0.36 & \\
\hline 18.4 & & & & 0.28 & -0.38 & & & & \\
\hline 18.9 & 0.13 & -0.51 & & & & & & & \\
\hline 20.7 & & & & & & & 0.13 & -0.70 & \\
\hline 21.4 & & & & 0.01 & -0.73 & & & & \\
\hline 21.7 & -0.23 & -1.01 & & & & & & & \\
\hline
\end{tabular}




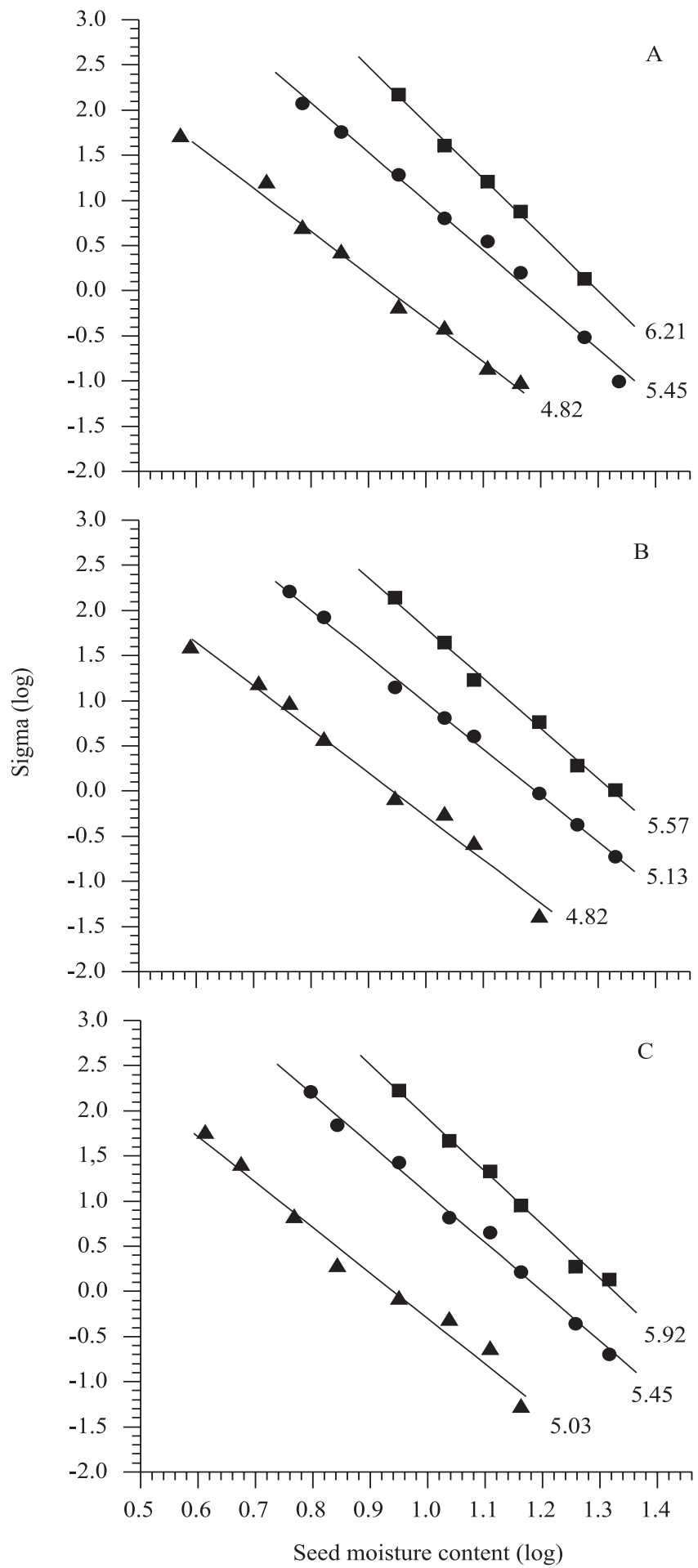

Figure 1. Relations between the logarithm of seed moisture content (\%, f. wt.) and the logarithm of sigma for cotton seedlots 1, 2 and 3 (A, B, C), stored at 40 (solid square), 50 (solid circle) and $65^{\circ} \mathrm{C}$ (solid triangle), respectively. Solid lines represent the regression lines for each storage temperature; line slopes are displayed in the figure. constants obtained define the equation at 40,50 and $65^{\circ} \mathrm{C}$, i.e., $\mathrm{K}=7.554,6.208$ and 4.571 and $\mathrm{C}_{\mathrm{W} 40^{\circ} \mathrm{C}}=5.736$, 5.728, 5.673; $\mathrm{C}_{\mathrm{W} 50^{\circ} \mathrm{C}}=5.248,5.221,5.146$; $\mathrm{C}_{\mathrm{W} 65^{\circ} \mathrm{C}}=4.887,4.857,4.856$ for seedlots 1,2 and 3 , respectively. The critical mc calculated below which no further increase in longevity occurred during hermetic storage at $65^{\circ} \mathrm{C}$, was $3.6 \%$.

The relationship between seed $\mathrm{mc}$ and the equilibrium relative humidity at $20^{\circ} \mathrm{C}$ is shown in Figure 2 . The third order polynomial curve $\left(r^{2}=0.98\right)$ represents a combination of sorption and desorption isotherms, depending on whether the values were obtained above or below the initial mc value (around 8.8\%).

The isotherm obtained consists of three regions: one, at low moisture contents, in which moisture rises steeply for a small increase in RH (water sorption at strong binding sites); a second region, at intermediate moisture contents, in which the gradient is shallow (water sorption at weak binding sites) and a third region, at high moisture contents, in which moisture increases again more steeply for a small increase in RH (water sorption binding to already absorbed water molecules) (Vertucci \& Leopold, 1987). Similar

Table 2. Statistical analyses for cottonseed cultivars 1, 2 (IAC 20) and 3 (IAC 19), stored at 40,50 and $65^{\circ} \mathrm{C}$, after constraining all survival curves to the same origin point $\left(\mathrm{K}_{\mathrm{i}}\right)$.

\begin{tabular}{|c|c|c|c|c|}
\hline Source & SS & DF & MS & $\mathrm{F}$ \\
\hline & \multicolumn{4}{|c|}{$40^{\circ} \mathrm{C}$} \\
\hline Cultivar & 0.01446 & 2 & 0.00723 & $1.39^{\mathrm{ns}}$ \\
\hline Lmc & 11.39 & 1 & 11.39 & $* *$ \\
\hline Cultivar vs. Lmc ${ }^{(1)}$ & 0.02093 & 2 & 0.010465 & $2.02^{\mathrm{ns}}$ \\
\hline Error & 0.062261 & 12 & 0.00519 & \\
\hline \multirow[t]{2}{*}{ Total } & 11.488 & 17 & & \\
\hline & \multicolumn{4}{|c|}{$50^{\circ} \mathrm{C}$} \\
\hline Cultivar & 0.05021 & 2 & 0.025105 & $2.81^{\mathrm{ns}}$ \\
\hline Lmc & 31.69 & 1 & 31.69 & ** \\
\hline Cultivar vs. Lmc & 0.02436 & 2 & 0.01218 & $1.36^{\mathrm{ns}}$ \\
\hline Error & 0.18761 & 21 & 0.00893 & \\
\hline \multirow[t]{2}{*}{ Total } & 31.927 & 26 & & \\
\hline & \multicolumn{4}{|c|}{$65^{\circ} \mathrm{C}$} \\
\hline Cultivar & 0.004895 & 2 & 0.00245 & $0.14^{\mathrm{ns}}$ \\
\hline Lmc & 20.95 & 1 & 20.95 & $* *$ \\
\hline Cultivar vs. Lmc & 0.008918 & 2 & 0.00446 & $0.26^{\mathrm{ns}}$ \\
\hline Error & 0.30554 & 18 & 0.01697 & \\
\hline \multirow[t]{2}{*}{ Total } & 21.268 & 23 & & \\
\hline & \multicolumn{4}{|c|}{$40,50,65^{\circ} \mathrm{C}$} \\
\hline Lmc & 34.56 & 1 & 34.56 & ** \\
\hline Treat & 40.18 & 2 & 20.09 & $* *$ \\
\hline Lmc vs. Treat & 0.1941 & 2 & 0.09705 & $9.54 * *$ \\
\hline Cultivar & 0.05376 & 2 & 0.02688 & $2.86^{\mathrm{ns}}$ \\
\hline Cultivar vs. Lmc & 0.003398 & 2 & 0.00170 & $0.17^{\mathrm{ns}}$ \\
\hline Error & 0.60010 & 59 & 0.01017 & \\
\hline Total & 75.584 & 68 & & \\
\hline
\end{tabular}

${ }^{(1)}$ Logarithm of moisture content. ns No statistical difference at $\mathrm{p}<0.01$. ${ }^{* *}$ Statistical difference at $\mathrm{p}<0.01$. 
results have been recorded by Barker \& Laird (1997), during moisture sorption/desorption experiments, using gin run cottonseeds, kept at $20^{\circ} \mathrm{C}$.

The inflection point of the isotherm (around 3.6\% mc) means the difference between the first and the second type of bound water, so it could account for the discontinuity among seed longevity and the lowest seed moisture contents; it can be that seed longevity increases according to mc reduction until the weak bound water was completely removed. These results are similar to those obtained by Simpson \& Miller (1944) using samples of cottonseed cultivar Stoneville, placed in desiccators over concentrated sulphuric acid solutions.

Desiccation below 6\% mc level resulted in hardseededness, with a progressive increase from this value to the lowest one, i.e., $2.2 \% \mathrm{mc}$, with similar trends for each seedlot (Figure 3). Mai-Hong et al. (2003) reported that hardseededness began to be induced when Peltophorum pterocarpum seeds were dried to about $15 \%$ moisture content and below, with a negative

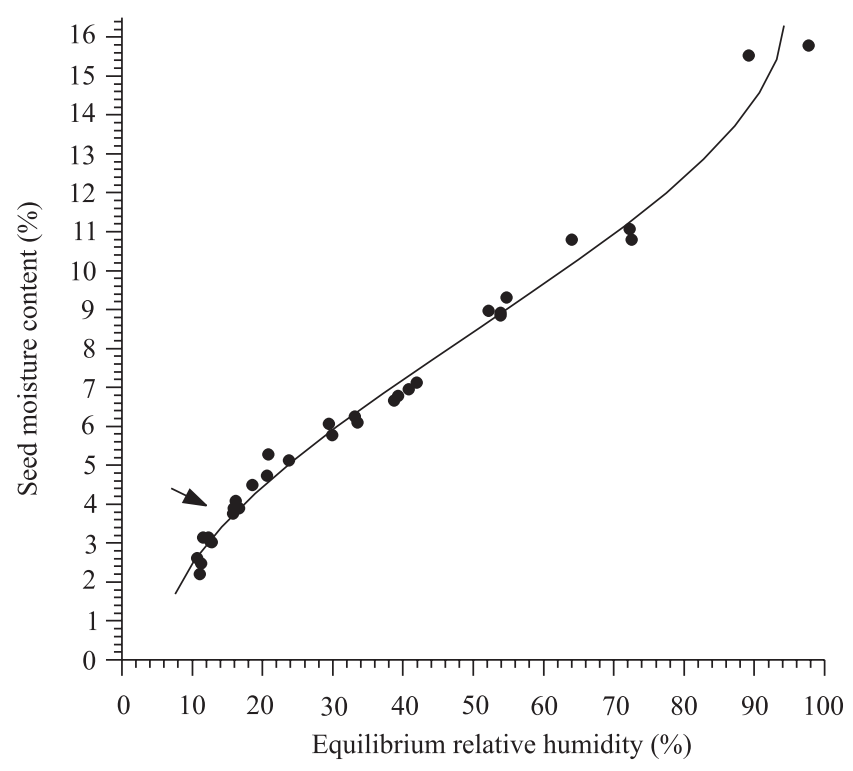

Figure 2. Relationship between seed moisture content (mc, \%, f. wt.) and the equilibrium relative humidity (\%) of cottonseed, at $20^{\circ} \mathrm{C}$. The curve represents sorption and desorption isotherms, above and below the initial moisture content value (8.8\%), respectively. The arrow points out to the inflection point of the isotherm $(3.6 \% \mathrm{mc})$, which means the lowest moisture content limit for application of the viability equation.

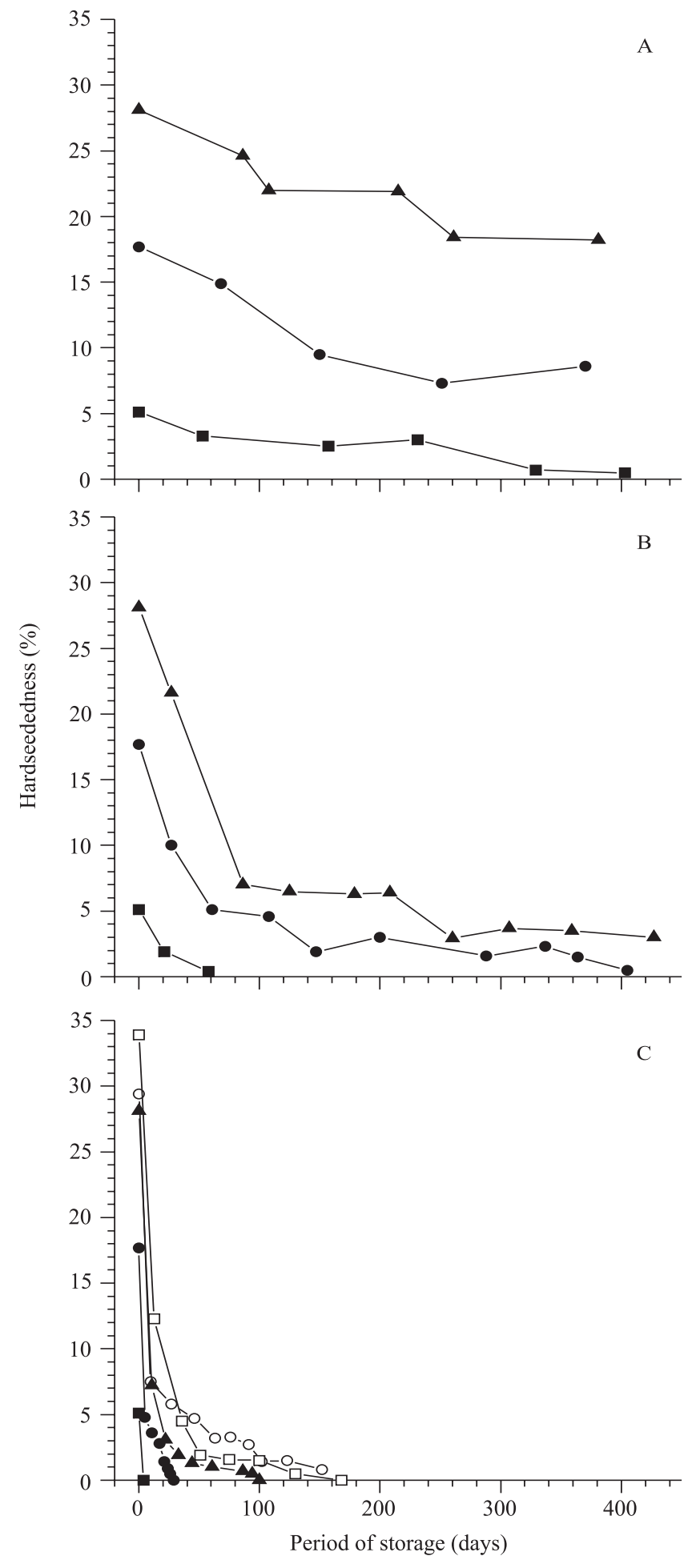

Figure 3. Hardseededness incidences in cottonseed after drying on silica gel, stored at: (A) $40^{\circ} \mathrm{C}$; (B) $50^{\circ} \mathrm{C}$ and $3.9 \%$ (solid triangle), $4.9 \%$ (solid circle) and 6.0\% (solid square) mc; (C) $65^{\circ} \mathrm{C}$ and $2.4 \%$ (open square), 3.1 (open circle), $3.9 \%$ (solid triangle), $4.9 \%$ (solid circle) and 6.0\% (solid square) mc. 
logarithmic relation between hardseededness and moisture content below this value.

The establishment of hardseededness has already been detected in three cotton hard seed lines by Delouche et al. (1995), when the seed mc first decreased to about $10 \%$ and increased to a maximum incidence at $4 \%$ mc. In this work, hardseededness depletion was achieved either naturally according to the increase of both storage temperature and storage period or artificially through seed coat removal after seven days of germination test, according to International Seed Testing Association (2004). In Dimorphandra mollis, the hardseededness depletion was achieved through sandpaper scarification (Chaves \& Usberti, 2004).

Figure 4 displays the relations between the logarithm of seed mc and the logarithm of the frequency distribution of seed deaths in time (sigma), at 40,50 and $65^{\circ} \mathrm{C}$. The slopes of the curves are similar, allowing to get accurately the constants of the viability equation. The dotted line, relating to seed moisture contents below 3.1\% shows a clear change of the logarithmic trend at $65^{\circ} \mathrm{C}$, since the

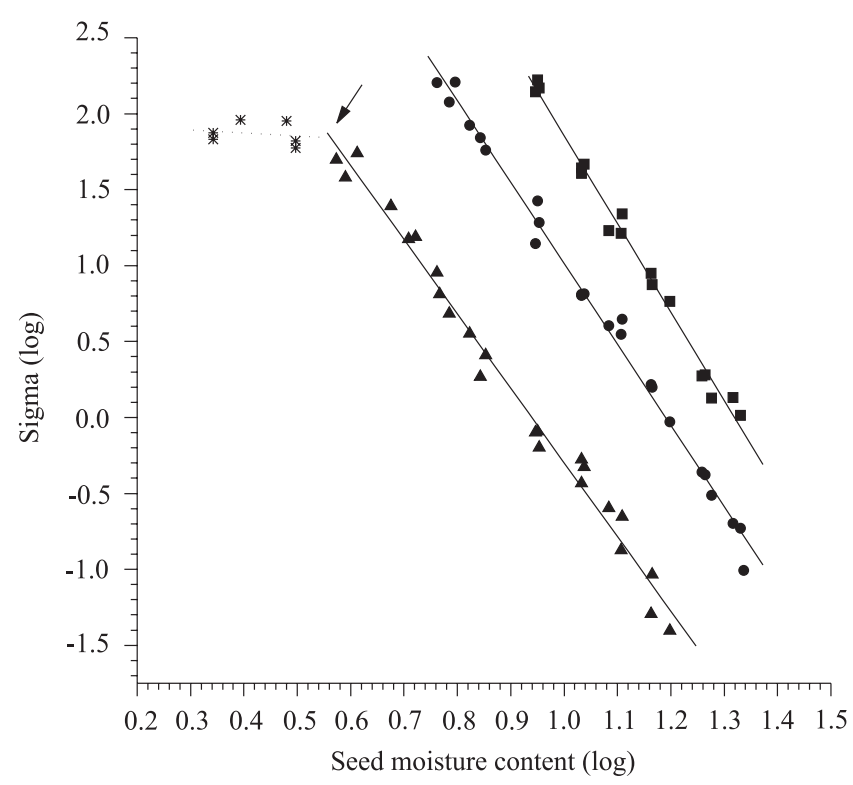

Figure 4. Relationship between the logarithm of seed moisture content and the logarithm of sigma for cotton, stored at 40 (solid square), 50 (solid circle) and $65^{\circ} \mathrm{C}$ (solid triangle). Solid lines represent slopes, which are constrained to one common value. The dotted line shows a different trend, at $65^{\circ} \mathrm{C}$, below the lower limit for application of the viability equation, pointed out by the arrow. points are depicted below the lower limit for application of the viability equation ( $3.6 \% \mathrm{mc}$ ).

The constants $\mathrm{K}_{\mathrm{E}}$ and $\mathrm{C}_{\mathrm{W}}$ estimated in this work were 9.240 and 5.190. The values achieved for the constants $\mathrm{C}_{\mathrm{H}}=0.03965$ and $\mathrm{C}_{\mathrm{Q}}=0.000426$ show similarity to those obtained by Dickie et al. (1990) after the statistical analysis of 359 survival curves of eight species $\left(\mathrm{C}_{\mathrm{H}}=0.0329 ; \mathrm{C}_{\mathrm{Q}}=0.000478\right)$, therefore corroborates the accuracy of the results obtained and the reliability of the methodology used.

Thus, the viability equation to predict cottonseed longevity is: $\mathrm{V}=\mathrm{K}_{\mathrm{i}}-\mathrm{p} / 10^{9.240}-5.190 \log \mathrm{m}-0.03965 \mathrm{t}-0.000426 \mathrm{t}^{2}$.

This equation was checked using data relating to cottonseed performance under long-term storage conditions, i.e., at constant mc and temperature (Simpson, 1942, 1957; Stewart \& Duncan, 1976) and at variable mc and temperature (Usberti, 1984).Values for predicted and observed viability after storage were similar (Figure 5) and the average values of the percentage germination and those predicted through the viability equation (49.5 and $49.0 \%$, respectively) were not significantly different ( $\chi^{2}$ test).

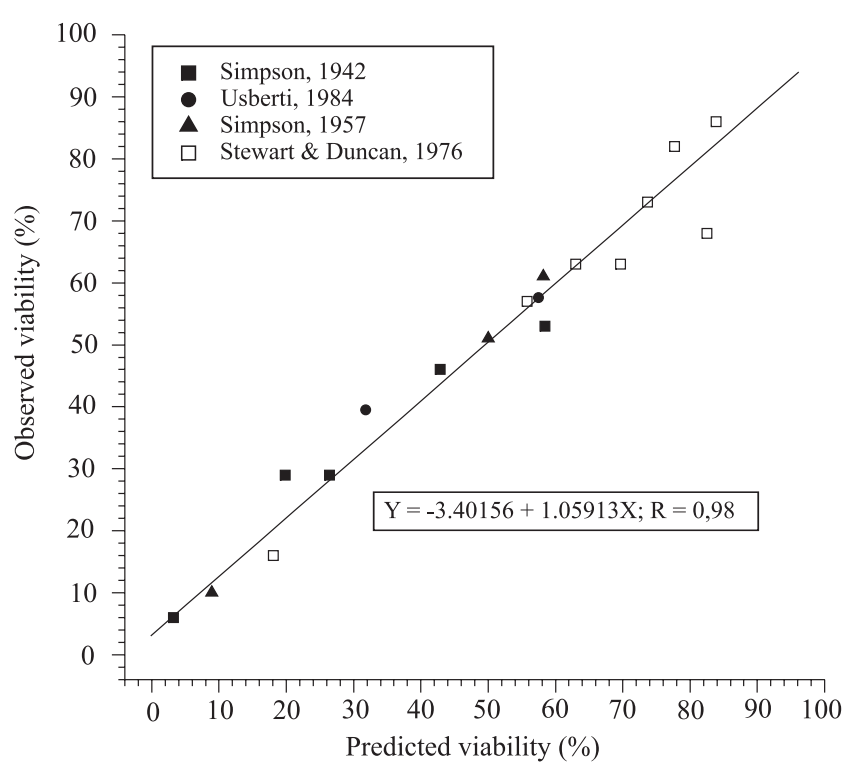

Figure 5. Observed and predicted cottonseed viability values

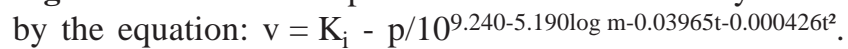
$\mathrm{K}_{\mathrm{i}}$ : initial viability; m: seed moisture content (f. wt. basis); $\mathrm{t}$ : storage temperature $\left({ }^{\circ} \mathrm{C}\right)$. 


\section{Conclusions}

1. A reliable equation is available to predict cottonseed longevity and its constants are $\mathrm{K}_{\mathrm{E}}=9.240 ; \mathrm{C}_{\mathrm{W}}=5.190$; $\mathrm{C}_{\mathrm{H}}=0.03965 ; \mathrm{C}_{\mathrm{Q}}=0.000426$.

2. The lower limit estimated for application of this longevity equation was 3.6\% moisture content.

3. Hardseededness occurs on moisture contents below $6 \%$ and its depletion was achieved either naturally during the storage period or artificially by seed coat removal.

\section{Acknowledgements}

To Conselho Nacional de Desenvolvimento Científico e Tecnológico and Fundação de Amparo à Pesquisa do Estado de São Paulo, Brazil, for financial support and for the grant to the first author.

\section{References}

BAKER, R.J.; NELDER, J.A. The GLIM system. Release 3. Oxford: Numerical Algorithms Group, 1978. Various paginations.

BARKER, G.L.; LAIRD, J.W. Effect of temperature on the drying rate of gin run cotton seed. Transactions of the ASAE, v.40, p.891896, 1997.

BONNER, F.T. Viability equations for forest tree seeds. Seed Science and Technology, v.27, p.981-989, 1999.

CHAVES, M.M.F.; USBERTI, R. Controlled seed deterioration in Dalbergia nigra and Dimorphandra mollis, endangered Brazilian forest species. Seed Science and Technology, v.32, p.813-823, 2004.

DELOUCHE, J.C.; GUEVARA, C.; KEITH, B.C. Development, release and characteristics of the hard seed condition in cotton. In: BELTWIDE COTTON CONFERENCES, 1995, San Antonio. Proceedings. San Antonio: National Cotton Council, 1995. v.2, p.1121-1125.

DICKIE, J.B.; ELLIS, R.H.; KRAAK, H.L.; RYDER, K.; TOMPSETT, P.B. Temperature and seed storage longevity. Annals of Botany, v.65, p.197-204, 1990.

ELLIS, R.H.; HONG, T.D.; ROBERTS, E.H. A comparison of the low-moisture-content limit to the logarithmic relation between seed moisture and longevity in twelve species. Annals of Botany, v.63, p.601-611, 1989.
ELLIS, R.H.; HONG, T.D.; ROBERTS, E.H. A low-moisture-content limit to logarithmic relations between seed moisture content and longevity. Annals of Botany, v.61, p.405-408, 1988.

ELLIS, R.H.; HONG, T.D.; ROBERTS, E.H. Handbook of seed technology for genebanks: volume II: compendium of specific germination information and test recommendations. Rome: IBPGR Publ., 1985. 667p. (Handbooks for genebanks, 3).

ELLIS, R.H.; HONG, T.D.; ROBERTS, E.H. Logarithmic relationship between moisture content and longevity in sesame seeds. Annals of Botany, v.57, p.499-503, 1986.

ELLIS, R.H.; ROBERTS, E.H. Improved equations for the prediction of seed longevity. Annals of Botany, v.45, p.13-30, 1980.

HAY, F.R.; MEAD, A.; MANGER, K.; WILSON, F.J. One-step analysis of seed storage data and the longevity of Arabidopsis thaliana seeds. Journal of Experimental Botany, v.54, p.993-1011, 2003.

INTERNATIONAL SEED TESTING ASSOCIATION. International rules for seed testing: edition 2004. Bassersdorf, 2004. 410p.

KRAAK, H.L.; VOS, J. Seed viability constants for lettuce. Annals of Botany, v.59, p.343-349, 1987.

MAI-HONG, T.; HONG, T.D.; HIEN, N.T.; ELLIS, R.H. Onset of germinability, desiccation tolerance and hardseededness in developing seeds of Peltophorum pterocarpum (DC) K. Heyne (Caesalpinioideae). Seed Science Research, v.13, p.323-327, 2003.

MEDEIROS, A.C.S.; PROBERT, R.J.; SADER, R.; SMITH, R.D. The moisture relations of seed longevity in Astronium urundeuva (Fr. All.) Engl. Seed Science and Technology, v.26, p.289-298, 1998.

SIMPSON, D.M. Factors affecting the longevity of cottonseed. Journal of Agricultural Research, v.64, p.407-419, 1942.

SIMPSON, D.M. Long-time storage of cottonseed. Agronomy Storage, v.49, p.608-609, 1957.

SIMPSON, D.M.; MILLER, P.R. The relation of atmospheric humidity to moisture content in cottonseed. Journal of the American Society of Agronomy, v.35, p.957-959, 1944.

STEWART, J.M.; DUNCAN, E.N. Cottonseed viability after longtime storage. Agronomy Journal, v.68, p.243-244, 1976.

USBERTI, R. Determinação do potencial de armazenamento de lotes de sementes de algodoeiro. Revista Brasileira de Sementes, v.6, p.11-24, 1984.

USBERTI, R.; GOMES, R.B.G. Seed viability constants for groundnut. Annals of Botany, v.82, p.691-694, 1998.

VERTUCCI, C.W.; LEOPOLD, A.C. Water binding in legume seeds. Plant Physiology, v.85, p.224-231, 1987.

Received on September 21, 2005 and accepted on May 26, 2006 